
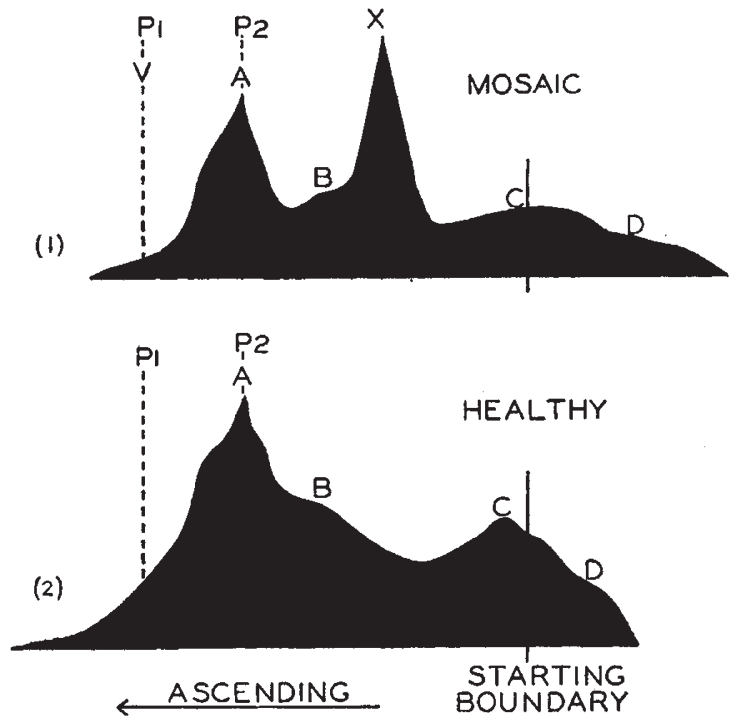

Electrophoretic scanning diagrams of extracts from (1) mosaic, and (2) healthy Turkish tobacco leaves. Infection period, 7 days $V$, Tobacco mosaic virus $X$, abnormal protein ; $A, B, C, D$ normal proteins, $P_{1} F_{2}$, coloured substances. Lxtracts prepared rom $200 \mathrm{gm}$. of fresh leaves using modifled virus removed by ultracentriugation, supernatant protein concentrat cacodylate buffer, $p \mathrm{H} 7 \cdot 0,15 \mathrm{~m}$.amp. $3 \mathrm{hr}$.

Its ultra-violet absorption maximum was $275 \mathrm{~m} \mu$ : Electron micrographs of this $X$-substance revealed the presence of indefinite roundish aggregates.

In the extracts of healthy leaves there is evidence of at least four other components (Fig. 2). Three are negatively charged $(A, B, C)$ and the fourth $(D)$ positively. Component $A$ was discovered earlier by Frampton and Takahashi and seems to be identical with Wildman, Cheo and Bonner's predominant protein, fraction I. Component $B$ has been tentatively identified as their fraction II. Near the starting boundary there appears to be at least one slow. moving component $C$. To the right of the boundary there is a suggestion of a positively charged component $D$. In addition, there are two coloured substances. The migration fronts of these are marked $P_{1}$ and $P_{2}$.

A comparison of Figs. 1 and 2 shows roughly that Wildman, Cheo and Bonner's predominant protein, $A$, decreases with increase of virus, and that components $B, C$ and $D$ apparently do likewise.

The origin of component $X$ in the diseased host and its significance in virus synthesis have yet to be explained. It is possible that it arises as a degradation product of some normal constituent of the host or is a by-product of deranged host metabolism. There is also the possibility that it is a relatively stable stage in the synthesis of the virus. If the latter can be proved to be the case, then tobacco mosaic virus does not multiply from fragments of pre-existing virus but is formed de novo.

William N. Takahashi MAMORU ISHII

Division of Plant Pathology,

University of California.

Oct. 16.

'Frampton, V. I.., and .Takahashi, W. N., Arch. Biochem., 2, 249 (1944).

"Wildman, S. G., Cheo, C. C., and Bonner, J., J. Biol. Chem., 180, 985 (1949).

${ }^{3}$ Chibnall, C. A., Miller, E. J., and Hugh, D., Biochem. J., 27, 1879

\section{'Solubilized' Chemicals for the Control of Plant Nematodes}

Work has already been published by one of $\mathrm{us}^{1}$ on the value of chlorphenol as a nematicide. The chlorphenol was used as an ordinary solution in water ; though of high toxicity to many species of eelworms, such as the stem and bulb eelworm (Ditytenchus dipsaci), it was not found effective against cyst-forming species such as the potato root eelworm (Heterodera rostochiensis).

Further work has now been carried out using chlorphenol and other chemicals in a 'solubilized' form ${ }^{2}$, produced by the use of detergents of the longchain alkyl sulphate type. Using the chemicals in this 'solubilized' form has resulted in a marked increase in toxicity coupled with powers of penetration which are of a high order. It has now been found that chlorphenol and allied compounds used in this way can not only penetrate the cysts of potato root eelworm lying in the soil, but also penetrate the egg-shells within the cysts and kill the enclosed larvæ. Other advantages of 'solubilization' are ease of solubility to levels in excess of normal solubility, increased wetting and penetration of the soil and increased persistence of the chemicals in the soil. Preliminary field experiments on tomatoes under glass and on potatoes in the open support our laboratory work.

It has also been found that a range of allied chemical compounds lend themselves to 'solubilization' and are also of high toxicity to eelworms. Briefly, the toxicity of chemicals we are working with is as follows. Ṕhenols are of low toxicity, cresols are of higher toxicity and the xylenols of higher toxicity still. When these compounds are chlorinated, the position is reversed, that is, the chlorphenols are the most toxic, the chlorcresols come next and the chlorxylenols are of low toxicity. With the chlorphenols the greater the degree of chlorination the higher the toxicity and the more phytotoxic the material becomes.

The investigation is now being actively pursued, and thanks are due to the Agricultural Research Council for providing the services of a full-time chemist (Miss J. K. Bartlett) to assist in the work.

A full account of this work will appear elsewhere in due course.

L. N. StaniLAND

L. E. W. STONE

Ministry of Agriculture,

National Agricultural Advisory Service,

"Bracken Hill",
Leigh Woods,
Bristol 8.

Oct. 16.

1 Staniland, I. N., J. Helminthology, 24, 91 (1950).

McBain, J. W., "Advances in Colloid Science", 1, 116 (Boston, Mass.).

\section{Simplified Embedding of Biological Material for Thin Sectioning}

SINCE the introduction of thin sectioning by conventional methods for electron microscopy in $1948^{1}$, several embedding techniques have been described ${ }^{1,2}$. In one of these, namely, double embedding in nitrocellulose and paraffin, the tissue is first infiltrated with an ether-alcohol solution of nitrocellulose ; the volume occupied by the solvent is then filled with 